JURNAL SAINTIFIK VOL. 1 NO. 2, JULI 2015

\title{
PENGEMBANGAN PERANGKAT PEMBELAJARAN MATEMATIKA MODEL KOOPERATIF TIPE STAD POKOK BAHASAN DALIL PYTHAGORAS
}

\author{
Rahmawati \\ STKIP YAPIM MAROS \\ e-mail: bokja_delta@yahoo.com
}

\begin{abstract}
Abstrak
Jenis penelitian ini adalah penelitian pengembangan yang bertujuan untuk mengembangkan perangkat pembelajaran berupa BS, LKS dan RPP yang valid, efektifdanpraktis.Penelitianinidilakukanpadakelas VIII ${ }_{6} M T s$ Negeri Model Makassar dengan subjek penelitian adalah siswakelas VIII. Instrumen dalam penelitian ini adalah(1) Lembar Pengamatan Aktivitas Siswa Selama Pembelajaran, (2) Lembar Pengamatan Aktivitas Guru Selama Pembelajaran, (3) Lembar Pengamatan Pengelolaan Pembelajaran dengan Model Kooperatif Tipe STAD, (4) Respon Siswa terhadap Kegiatan Pembelajaran, dan (5) TesHasilBelajar. Hasil penelitian menunjukkan bahwa hasil uji coba perangkat pembelajaran diuraikan sebagai berikut: (1) Skor rata-rata yang diperoleh siswa pada tes hasil belajar adalah 67,70 dari skor ideal 100 dengan standar deviasi 15,59. Banyaknya siswa yang tuntas belajara dalah 31 dari 40 orang (77,5\%). Data ini menunjukkan bahwa ketuntasan klasikal tercapai, (2) kategori aktivitas siswa yang diamati memenuhi Interval Toleransi PWIyang ditentukan, (3) Pada umumnya siswa memberikan respon positif terhadap perangkat pembelajaran matematika dengan model kooperatif tipe STAD, dan (4) Tingkat kemampuan guru mengelola pembelajaran dengan menggunakan model pembelajaran kooperatif tipe STAD termasuk dalam kategori sangat tinggi.
\end{abstract}

Kata Kunci: pengembangan perangkat, model kooperatif, tipe STAD, dalil Pythagoras

\section{PENDAHULUAN}

Salah satu model pembelajaran yang dapat digunakan dalam proses pembelajaran matematika adalah pembelajaran kooperatif. Pembelajaran kooperatif merupakan model pembelajaran yang akhir-akhir ini menjadi perhatian dan dianjurkan para ahli pendidikan untuk digunakan.Sebagaimana anjuran beberapa pakar di antaranya Slavin bahwa guru yang pertama kali menggunakan model pembelajaran kooperatif hendaknya memilih tipe STAD.

Salah satu unsur terpenting untuk terlaksananya pembelajaran kooperatif menurut Arends dan Ibrahim (Syarif, 2008) adalah perangkat pembelajaran yang sesuai untuk siswa. Oleh karena itu, sebelum melaksanakan pembelajaran dengan model kooperatif tipe STAD terlebih dahulu dilakukan pengembangan perangkat pembelajaran. Pengembangan ini diharapkan akan menghasilkan perangkat pembelajaran yang tepat untuk membantu siswa memahami konsep yang disajikan serta memberikan kemudahan bagi guru dalam mengajarkan konsep-konsep tersebut.

Berdasarkan uraian diatas, maka penulis termotivasi untuk mengadakan penelitian dengan judul "Pengembangan Perangkat Pembelajaran Matematika Model Kooperatif Tipe STADdalam Pokok Bahasan Dalil Pythagoras diMTs". 


\section{METODE PENELITIAN}

Jenis penelitian ini adalah Penelitian Pengembangan (Research and Development). Penelitian ini dilaksanakan di MTs Negeri Model Makassar tahun pelajaran 2008/2009, dengan subjek penelitian adalah siswa kelas $\mathrm{VIII}_{6}$ sebanyak 40 orang.

Adapunprosedurpelaksanaanpenelitianiniadalahsebagaiberikut:(1) Persiapan: Menelaah kurikulum MTs kelas VIII semester genap untuk pelajaran matematika, Mengembangkan perangkat pembelajaran yaitu buku siswa, lembar kerja siswa, dan rencana pelaksanaan pembelajaran, danMembuat lembar observasi untuk mengamati aktivitas siswa, aktivitas guru, dan pengelolaan pembelajaran di kelas. Membuat angket untuk mengetahui respon siswa tentang perangkat pembelajaran yang dikembangkan dengan model kooperatif tipe STAD, (2) Pelaksanaan: Membagi siswa ke dalam beberapa kelompok heterogen, Melaksanakan pembelajaran dengan model pembelajaran kooperatif tipe STAD,danSelama proses pembelajaran berlangsung dilakukan pengamatan aktivitas siswa dan kemampuan guru mengelola pembelajaran yang dilakukan oleh masing-masing satu orang pengamat, dan(3) analisis data: menganalisis data yang diperoleh dari tahap pelaksanaan.

Instrumen yang digunakan dalam penelitian ini yaitu lembar pengamatan aktivitas siswa selama pembelajaran, lembar pengamatan aktivitas guru selama pembelajaran, lembar pengamatan pengelolaan pembelajaran dengan model kooperatif tipe $S T A D$, respon siswa terhadap kegiatan pembelajaran, dan tes hasil belajar.Data yang telah dikumpulkan dengan menggunakan instrumen-instrumen, selanjutnya dianalisis secara kuantitatif dan diarahkan untuk menjelaskan kevalidan, keefektifan dan kepraktisan perangkat pembelajaran kooperatif tipe STAD yang tengah dikembangkan.Data yang diperoleh dari hasil validasi oleh para ahli dianalisis untuk menjelaskan kevalidan dan kelayakan penggunaanperangkat pembelajaran dengan model kooperatif tipe STAD di kelas.

\section{HASIL DAN PEMBAHASAN}

Berdasarkan hasil uji coba perangkat pembelajaran yang meliputi buku siswa, LKS, dan RPP diperoleh data hasil tes belajar siswa, data hasil pengamatan aktivitas siswa, respons siswa terhadap kegiatan dan perangkat pembelajaran dengan model pembelajaran kooperatif tipe STAD, data hasil pengamatan aktivitas guru, dan data hasil pengamatan pengelolaan pembelajaran model kooperatif tipe STAD. Data-data inilah yang digunakan untuk mengetahuikeefektifandankepraktisan perangkat pembelajaran dengan model pembelajaran kooperatif tipe STAD.

Dari 40 siswa yang mengikuti tes hasil belajar terdapat 5\% siswa yang termasuk dalam kategori sangat rendah, 17,5\% siswa yang termasuk dalam kategori rendah, 7,5\% siswa masuk dalam kategori sedang, 52,5\% masuk dalam kategori tinggi, dan siswa yang masuk dalam kategori sangat tinggi adalah sebesar $17,5 \%$. Hal ini menunjukkan bahwa kebanyakan siswa memperoleh pemahaman yang baik terhadap materi yang disajikan dengan menggunakan perangkat pembelajaran matematika dengan model pembelajaran kooperatif tipe STAD. Banyaknya siswa yang mencapai ketuntasan individu yaitu siswa yang memperoleh skor 60 100 sebanyak 31 orang siswa atau 77,5\%. Data ini menunjukkan bahwa ketuntasan klasikal tercapai.

Seluruh kategori aktivitas siswa yang diamati memenuhi Interval Toleransi PWI (\%) yang ditentukan. Artinya, kriteria pencapaian waktu ideal aktivitas siswatercapai. 
JURNAL SAINTIFIK VOL. 1 NO. 2, JULI 2015

\section{KESIMPULAN}

Skor rata-rata yang diperoleh siswa pada tes hasil belajar adalah 67,70 dari skor ideal 100 dengan standar deviasi 15,59. Banyaknya siswa yang tuntas belajar adalah 31 dari 40 orang (77,5\%). Data ini menunjukkan bahwa ketuntasan klasikal tercapai.Dengan menggunakan perangkat pembelajaran matematika dengan model kooperatif tipe STAD siswa dapat lebih aktif dalam proses pembelajaran. Dimana seluruh kategori aktivitas siswa yang diamati memenuhi Interval Toleransi PWI yang ditentukan.Pada umumnya siswa memberikan respon positif terhadap perangkat pembelajaran matematika dengan model kooperatif tipe STAD.Tingkat kemampuan guru mengelola pembelajaran dengan menggunakan model pembelajaran kooperatif tipe $S T A D$ termasuk dalam kategori sangat tinggi.

\section{DAFTAR PUSTAKA}

Darwis, Muhammad. 2007. Model Pembelajaran Matematika yang Melibatkan Kecerdasan Emisonal. Disertasi Program Pascasarjana Program Studi Pendidikan Matematika Universitas Negeri Surabaya. Tidak diterbitkan.

Dimyati, Mudjono. 1999. Belajar dan Pembelajaran. Jakarta: Rineka Cipta.

Haling, Abdul. 2007. Belajar dan Pembelajaran. Makassar: Badan Penerbit UNM.

Marsuki, Arnida. 2008. Pengembangan Perangkat Pembelajaran Matematika Berbasis Contextual Teaching and Learning Pokok Bahasan Perbandingan pada Siswa Kelas VII $I_{1}$ SMP Negeri 9 Makassar. Skripsi FMIPA UNM Makassar. Tidak diterbitkan.

Rohani. 1991. Pengelolaan Pengajaran. Jakarta: Rineka Cipta.

Salamah, Umi. 2007. Membangun Kompetensi MATEMATIKA untuk Kelas VIII SMP dan MTs. Solo: Tiga Serangkai Pustaka Mandiri.

Slavin, R. E. 2008. Cooperative Learning (Teori, Riset, dan Praktik). Bandung: Nusa Media.

Suherman, Erman. 1986. Buku Materi Pokok Pengelolaan Kelas dan Interaksi Belajar Mengajar Matematika. Jakarta: Depdikbud.

Syarif, Rusman. 2008. Pengembangan Perangkat Pembelajaran Matematika Pokok Bahasan Operasi Hitung pada Bentuk Aljabar dalam Model Pembelajaran Kooperatif Tipe

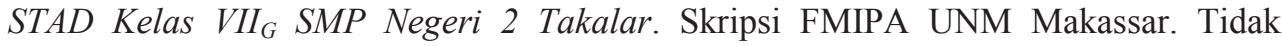
Diterbitkan.

Upu, Hamzah. 2005. Karakteristik Research and Development (R\&D), Jurnal Eksponen edisi Khusus. Makassar: Jurusan Matematika FMIPA Universitas Negeri Makassar.

Yunus, Ummiyati. 2008. Pengembangan Perangkat Pembelajaran Kooperatif Berbasis Contextual Teaching and Learning pada Pokok Bahasan Garis di SMP Negeri 6 Pangsid. Skripsi FMIPA UNM Makassar. Tidak diterbitkan.

DoantaraYasa,MetodePembelajaranKooperatif,

http://ipotes.wordpress.com/2008/05/10/metode-pembelajaran-kooperatif/, diaksestgl 28 Mei 2009.

Holil,Anwar. Model Pembelajaran Kooperatif.

http://anwarholil.blogspot.com/2007/09/pendidikan-inovatif.html. Diaksestgl 28 Mei 2009. 